\title{
Transnational Plastics: An Australian Case for Global Action
}

\author{
Ronen Galaiduk ${ }^{1}$, Laurent Lebreton ${ }^{2,3}$, Erika Techera ${ }^{4,5}$ and Julia Reisser ${ }^{5 *}$ \\ ${ }^{1}$ Australian Institute of Marine Science, Crawley, WA, Australia, ${ }^{2}$ The Modelling House, Raglan, New Zealand, ${ }^{3}$ The Ocean \\ Cleanup Foundation, Delft, Netherlands, ${ }^{4}$ UWA Law School, The University of Western Australia, Perth, WA, Australia, \\ ${ }^{5}$ UWA Oceans Institute, The University of Western Australia, Perth, WA, Australia
}

\section{OPEN ACCESS}

Edited by:

André Ricardo Araújo Lima,

Center for Marine and Environmental

Sciences (MARE), Portugal

Reviewed by:

Kryss Waldschläger,

RWTH Aachen University, Germany

Tony Robert Walker,

Dalhousie Univesity, Canada

*Correspondence:

Julia Reisser

jureisser@gmail.com

Specialty section:

This article was submitted to

Toxicology, Pollution and the

Environment,

a section of the journal

Frontiers in Environmental Science

Received: 09 May 2020

Accepted: 30 June 2020

Published: 22 July 2020

Citation:

Galaiduk R, Lebreton L, Techera E and Reisser J (2020) Transnational

Plastics: An Australian Case for Global Action. Front. Environ. Sci. 8:115. doi: 10.3389/fenvs.2020.00115
Mitigating plastic pollution requires strong international cooperation because significant volumes of plastic waste are transported across jurisdictions both as waste exports and drifting ocean plastics (OP). Here we estimate which nations are (1) sources for overseas $\mathrm{OP}$ reaching Australian waters and (2) destinations receiving OP from Australian sources. We then provide actionable recommendations for mitigating plastic pollution in Australian waters and beyond. We estimated that the vast majority of overseas OP reaching Australia is from Indonesia, and that most of the Australian-sourced OP reaching overseas territories is entering New Zealand. Key actions for mitigating the $\mathrm{OP}$ issue in Australia include better governance, upgraded enforcement, and increased investments to reduce fossil fuel-based plastic production and to drastically improve both domestic and international waste management infrastructure and operations.

Keywords: marine pollution, marine debris, plastic pollution, Australia, connectivity, ocean currents

\section{INTRODUCTION}

Plastic pollution is a global environmental concern due to its widespread damage to ecosystems, economies, and human well-being. Under a "business as usual" scenario, plastic impacts will keep increasing as both the production and mismanagement rates of these materials are high and rising. Globally, we are currently producing $\sim 380$ million tons of plastic per year, with just $9 \%$ of it being recycled; the rest is burned, landfilled, or dumped in the environment (Geyer et al., 2017). Notoriously, around $40 \%$ of the plastics we produce are used for packaging that becomes waste immediately after its single use, contributing to more than $60 \%$ of global beach litter (Schweitzer et al., 2018). Currently, more than 15 million tons of plastic enter oceans each year (Forrest et al., 2019). Plastics of all kinds-from microscopic packaging fragments to giant fishing nets-have accumulated in many marine ecosystems, including beaches (Lavers and Bond, 2017), coastal and oceanic waters (Ryan, 2013; Lebreton et al., 2018), marine canyons (Schlining et al., 2013), coral reefs (Lamb et al., 2018), mangroves (Martin et al., 2019), and even sea ice (Peeken et al., 2018). Pronounced marine plastic pollution impacts include the often lethal consequences of entanglement and ingestion interactions between ocean plastics (OP) and marine wildlife (Vegter et al., 2014). Other more subtle OP implications include transport of invasive species across ocean basins (Barnes, 2002) and release of persistent bioaccumulative toxic (PBTs) chemicals into environments and organisms, with the potential bioaccumulation of plastic-associated PBTs up food webs that include humans as seafood consumers (Setälä et al., 2014; Rochman et al., 2015; Chen et al., 2018). Aside from impacting oceans, plastics are also causing significant damage during their upstream lifecycle. The vast majority of today's plastics are made of fossil fuels $(\sim 99 \%)$ and the release of greenhouse gases during their production and incineration is costing around 
US\$ 700 billion per year to the global economy (Forrest et al., 2019). Additional damage is created by the release of toxic chemicals from plastics to air, soil and water resources (UNEP, 2014) as well as human exposure to plastic particles and additives linked to cancer, obesity, diabetes, and endocrine system disorders (Brophy et al., 2012; DeMatteo et al., 2013; Manikkam et al., 2013; Lehner et al., 2019).

To solve plastic pollution, countries around the world need better governance at the municipal (e.g., Cohen et al., 2015), national (e.g., Commonwealth of Australia, 2018a), regional (e.g., European Commission, 2019), and international levels (Borrelle et al., 2017; Weikard, 2019). The last of these is particularly complex but essential given the transboundary nature of plastic contamination, particularly as wide OP dispersal (Lebreton et al., 2012) and waste trade (Brooks et al., 2018) (Table 1). Most of the global plastic waste is generated by high-income countries (HICs), where per capita plastic consumption is particularly high (Hoornweg and Bhada-Tata, 2012). As recycling is a low margin business, the majority of HICs plastic waste intended for recycling is exported to lower income "East Asia and Pacific" nations with low labor costs (Locock, 2017). Australia is a classic example of a HIC "plastic waste exporter" as it ships large volumes of plastic waste to low- to middle-income countries (LMICs). In 2018 alone, Australia exported $\sim 127,400$ tons of plastic waste (UN Trade Statistics, 2018; code 3915 "waste, parings and scrap of plastics"), the majority of which was exported to Malaysia (35\%), Indonesia (22\%), and Thailand (18\%; Figure 1). Historically, plastic waste trade has been associated with serious environmental and social issues, including export of low-quality plastic bales by HICs and illegal practices for processing imported materials by LMICs, including labor exploitation, burning, and discard of low-value plastic waste into dumps, rivers, and oceans (GAIA, 2019; Sarpong, 2020). A significant disruption to global plastic waste trade occurred in 2017, when China banned the import of large volumes of plastic waste into its territory (Liu et al., 2018; Walker, 2018) and neighboring LMICs started receiving this rejected waste (Wang et al., 2019). These LMICs lack the infrastructure to manage their own plastic waste, let alone a rapid increase in plastic waste supplied by HICs. The international plastic waste crisis is now quite evident, with wasteimporting countries such as Malaysia and Indonesia starting to ship contaminated plastic waste back to its HICs sources (CNN, 2019; Walden and Renaldi, 2019). Without improved plastic waste governance, there is a risk that increasing quantities will ultimately become plastic pollution.

Plastic waste is not only exchanged between nations via trade. Once leaked into rivers and oceans, it can be transported by currents, winds, and waves, often polluting other nations' exclusive economic zones (EEZs) (Lavers and Bond, 2017; Lebreton et al., 2017). It is quite difficult to track OP back to sources, with the degree of difficulty increasing over time as OP items undergo environmental weathering and fragmentation into progressively smaller pieces known as microplastics when $<5 \mathrm{~mm}$ and nanoplastics when $<0.1 \mu \mathrm{m}$ (Gigault et al., 2018). Previous studies attempting to quantify OP connectivity dynamics have utilized 2D numerical models forced by sea surface current velocity fields to simulate OP transport
TABLE 1 | Top five nations with the highest mass of plastic waste exported ("Top Exporters") and leaked to oceans ("Top Emitters").

\begin{tabular}{llclr}
\hline Rank & Top exporters & Tons & Top emitters & \multicolumn{1}{c}{ Tons } \\
\hline 1 & Germany & $1,266,787$ & China & $2,425,422$ \\
2 & United States & $1,217,145$ & Indonesia & 884,635 \\
3 & Japan & $1,035,421$ & Philippines & 518,006 \\
4 & United Kingdom & 756,106 & Vietnam & 504,300 \\
5 & France & 441,705 & Thailand & 282,628 \\
\hline
\end{tabular}

Numbers are mass estimates of nations' plastic waste exports in 2018 (UN Trade Statistics, 2018) and emitted to oceans in 2010 (Jambeck et al., 2015; after correction for Sri Lanka data, as described in Lebreton et al., 2017).

at different scales (Lebreton et al., 2012; Eriksen et al., 2014; Critchell and Lambrechts, 2016). To the best of our knowledge, there are no studies to date attempting to quantify fluxes of OP between nations. This information is key to better inform stakeholders involved in designing cost-effective strategies for decreasing OP pollution. In this policy brief, we used ocean modeling to estimate which nations are (1) sources for overseas OP reaching Australian waters and (2) destinations receiving OP of Australian origin. Using our findings and incorporating an extensive literature review, we then describe governance and policy recommendations for mitigating plastic pollution in Australia and beyond.

\section{ORIGIN AND DESTINATIONS OF OCEAN PLASTICS CROSSING THE AUSTRALIAN EEZ}

We used a Lagrangian model that simulated inputs and surface transport of OP in the world's oceans (Lebreton et al., 2012) to estimate connectivity between the Australian EEZ and other world countries' EEZs. Our analysis indicated that the vast majority of overseas OP reaching the Australian EEZ is coming from Indonesia ( $\sim 70.5 \%$; Figure 2$)$, followed by Fiji $(\sim 8 \%)$, Vanuatu ( 4\%), Papua New Guinea ( 3\%), Philippines $(\sim 2.5 \%)$, Vietnam $(\sim 2.5 \%)$, East Timor $(\sim 2 \%)$, South Africa $(\sim 2 \%)$, China $(\sim 1.5 \%)$, Malaysia $(\sim 1 \%)$, Solomon Islands $(1 \%)$, and other minor contributions ( $\sim 3 \%$ ) from 19 nations: Sri Lanka, Thailand, Samoa, Maldives, Tanzania, Comoro Islands, New Zealand, Myanmar, Mozambique, Peru, Mauritius, Singapore, Pakistan, Kenya, Madagascar, and Ecuador. In relation to Australiansourced OP reaching overseas EEZs, we predicted that $~ 78 \%$ is entering New Zealand waters, with the remaining reaching the EEZs of New Caledonia $(\sim 17.5 \%)$, Fiji $(\sim 4 \%)$, and Vanuatu $(\sim 1 \%)$.

Our model released "virtual OP" particles in the world's EEZs at rates proportional to estimated volumes of mismanaged plastic waste per country (Jambeck et al., 2015) and derived their transport from sea surface current velocity fields sourced from the HYCOM + NCODA global reanalysis (Fox et al., 2002; Cummings, 2005; Cummings and Smedstad, 2013). For every day between 1993 and 2012, we documented the number of particles inside the Australian EEZ arriving from each foreign country as well as the number of particles of Australian origin inside the EEZ 


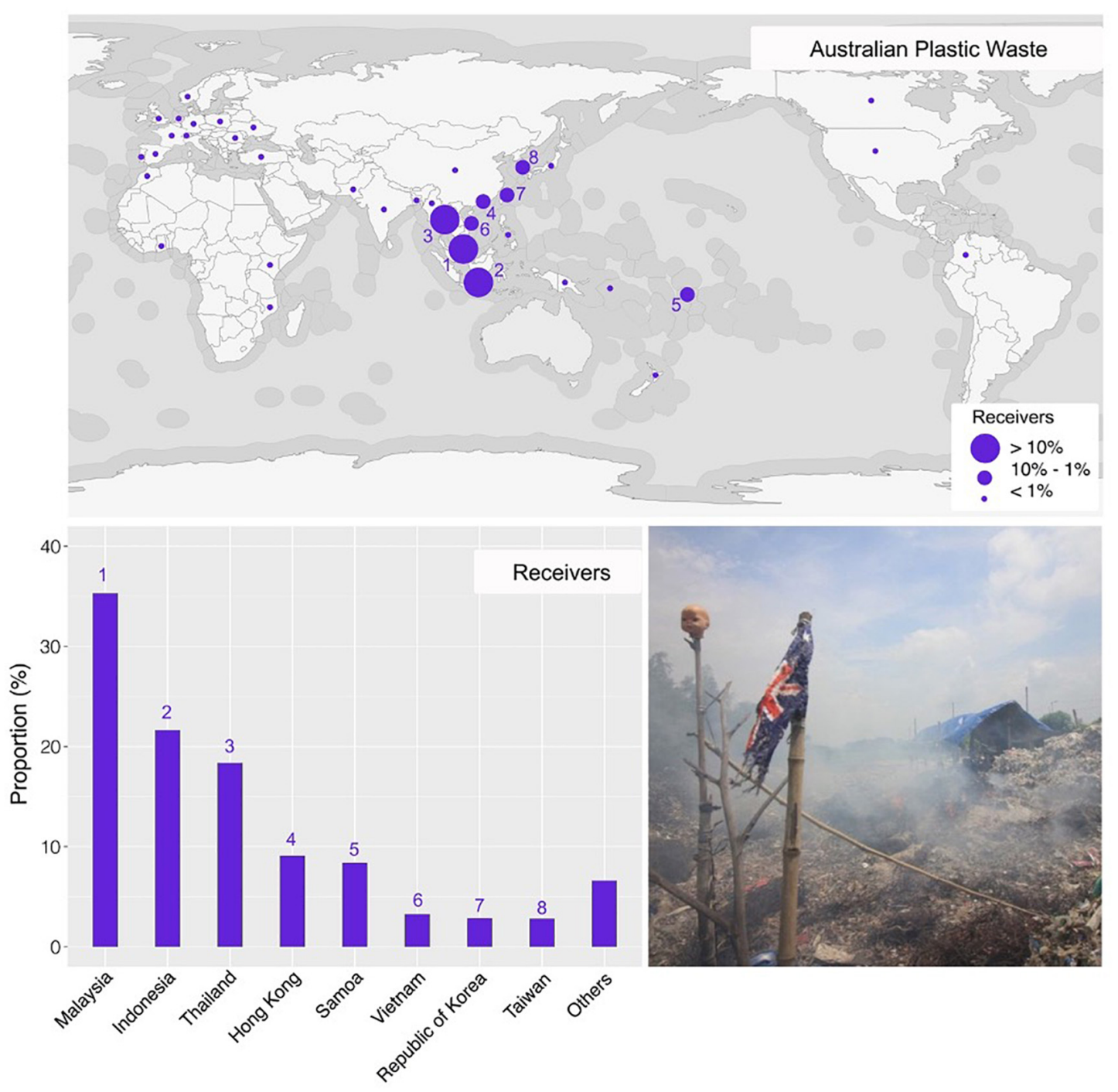

FIGURE 1 | Countries identified as destinations for plastic waste exported by Australia in 2018 (UN Trade Statistics, 2018). The map indicates countries receiving Australian plastic waste, with circle sizes proportional to amounts exported in 2018. Top Australian waste importers are (1) Malaysia, (2) Indonesia, (3) Thailand, (4) Hong Kong, (5) Samoa, (6) Viet Nam, (7) Taiwan, and (8) Republic of Korea. Histogram shows the proportion of exported Australian plastic waste reaching its major destinations in 2018. Image shows mismanagement of Australian waste (i.e., burning of low-value plastics) in Surabaya, Indonesia. Image source:

Ecoton-http://ecoton.or.id/en/home/.

of every other country. We averaged the daily number of visits per emitting country over the total number of particles present in the model and over the full 20-year period. It is important to emphasize that our model considered an infinite lifetime for virtual OP particles floating at the sea surface. As a consequence, significant OP removal processes such as beaching (Olivelli et al., 2020) and sinking (Porter et al., 2018) were not accounted for. Nonetheless, we know that a proportion of floating OP is persistent enough to travel long distances (Lebreton et al., 2018). Therefore, assuming removal processes have similar magnitudes across countries of origin, our predictions of international OP connectivity are reasonable.

The occurrence of Indonesian-based plastics reaching the Australian EEZ and shorelines is in line with field observations
(Reisser et al., 2013). Significant OP accumulation zones dominated by Indonesian-based debris from both on-land (e.g., mismanaged single-use packaging) and at-sea (e.g., dumped fishing nets) sources have been recorded in a range of Australian regions such as Gulf of Carpentaria (Wilcox et al., 2013; Dhimurru Aboriginal Corporation, 2018), Christmas Island (Lavers et al., 2020), Cocos Island (Lavers et al., 2019), and Ashmore Reef (Lavers et al., 2013; Figure 3). This is not surprising since the waters and shorelines of North West Australia, North Queensland, and Northern Territory are exposed to OP originated in Indonesia's EEZ due to both geographic proximity and ocean hydrodynamics (Sprintall et al., 2019). The accumulation of OP in remote regions of Australia is quite concerning given ingestion and entanglement interactions 


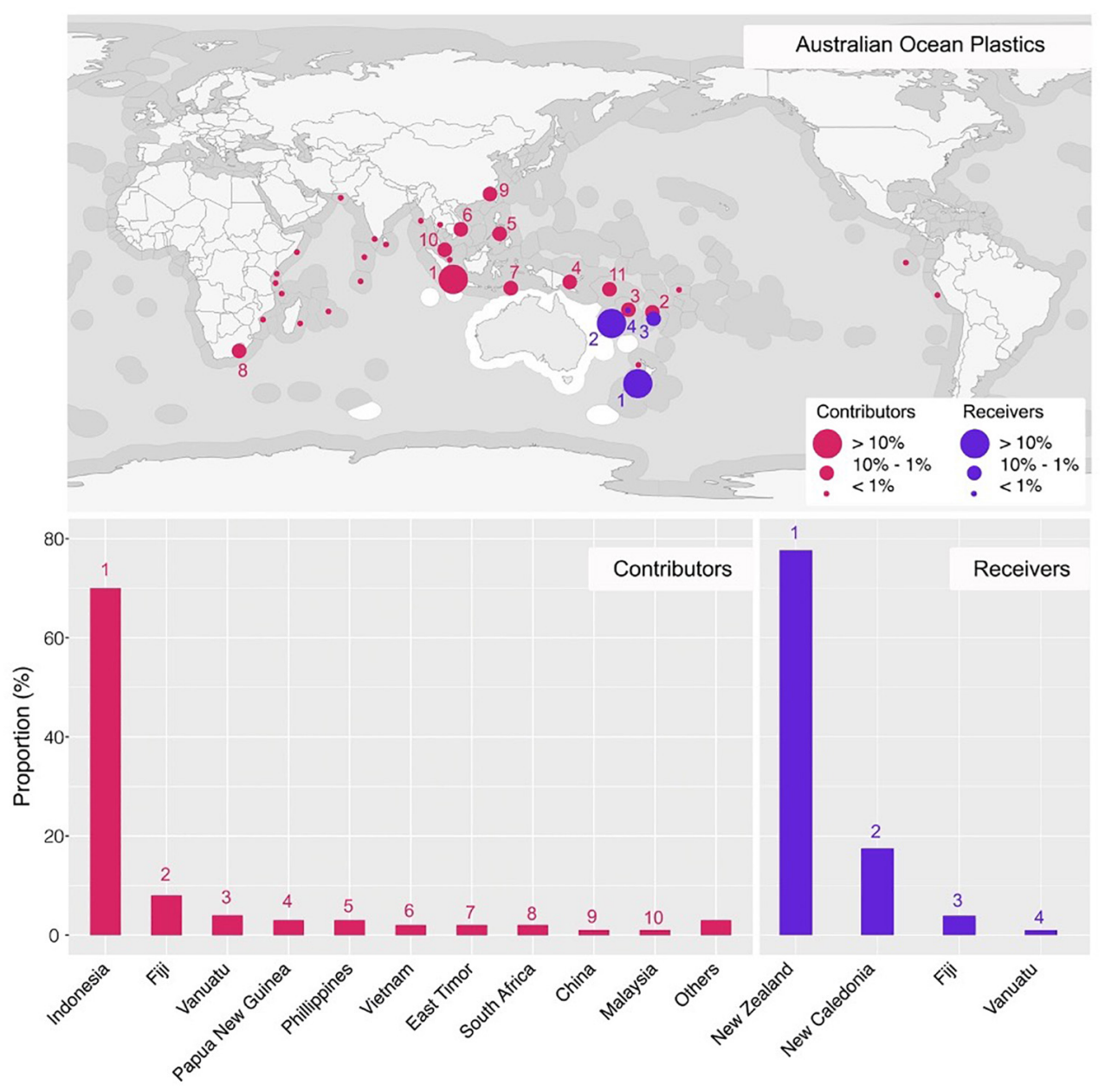

FIGURE 2 | Countries identified as sources (pink) and destinations (blue) for ocean plastics (OP) crossing the Australian Economic Exclusive Zone (EEZ) boundary. The map indicates country locations, with circle sizes proportional to amounts of OP reaching the Australian EEZ (pink) or receiving Australian-based OP (blue). The Australian EEZ is highlighted in white. Top "source countries" are (1) Indonesia, (2) Fiji, (3) Vanuatu, (4) Papua New Guinea, (5) Philippines, (6) Vietnam, (7) East Timor, (8) South Africa, (9) China, (10) Malaysia, and (11) Solomon Islands. Ranking of "destination countries" is (1) New Zealand, (2) New Caledonia, (3) Fiji, and (4) Vanuatu. Histogram in the left shows the contributions of "source nations" for overseas OP reaching Australian waters. Histogram in the right shows the proportion of OP from Australian sources reaching "destination countries."

with endangered marine wildlife (e.g., sea turtles; Wilcox et al., 2013), cross-boundary transport of pollutants and organisms (Reisser et al., 2014; Yeo et al., 2015; Lamb et al., 2018), damage to tourism, and remote clean-up costs (Commonwealth of Australia, 2018b).

\section{GOVERNANCE AND POLICY RECOMMENDATIONS}

This study highlights the transboundary nature of a major issue associated with our broken "plastics economy": persistent waste that creates high and ever-increasing levels of widespreading pollution. As of today, there are only a few global interventions dealing with specific plastic pollution issues (Table 2) and although the United Nations Convention on the Law of the Sea (UNCLOS, 2020) requires the adoption of laws and standards to prevent, reduce, and control landbased pollution, these have not yet eventuated (Article 207). The existing initiatives are quite fragmented and uncoordinated, with no overarching binding commitment to jointly tackle all facets of our transnational plastics crisis. Like others (Borrelle et al., 2017; Simon and Schulte, 2017; Haward, 2018; Raubenheimer and McIlgorm, 2018; Vince and Stoett, 2018; Tessnow-von Wysocki and Le Billon, 2019; Weikard, 2019; Raubenheimer and Urho, 2020), we believe it is important to create a new global convention that establishes a legally binding framework for global plastics governance. As suggested by Simon and Schulte (2017), the form of such convention should reflect both great ambition and political feasibility, as to ensure agreeability between and finally compliance by state parties. It could be built on five pillars: (1) a clear and binding goal to eliminate plastic contamination of water, food, air, land, and oceans; (2) strategic options 


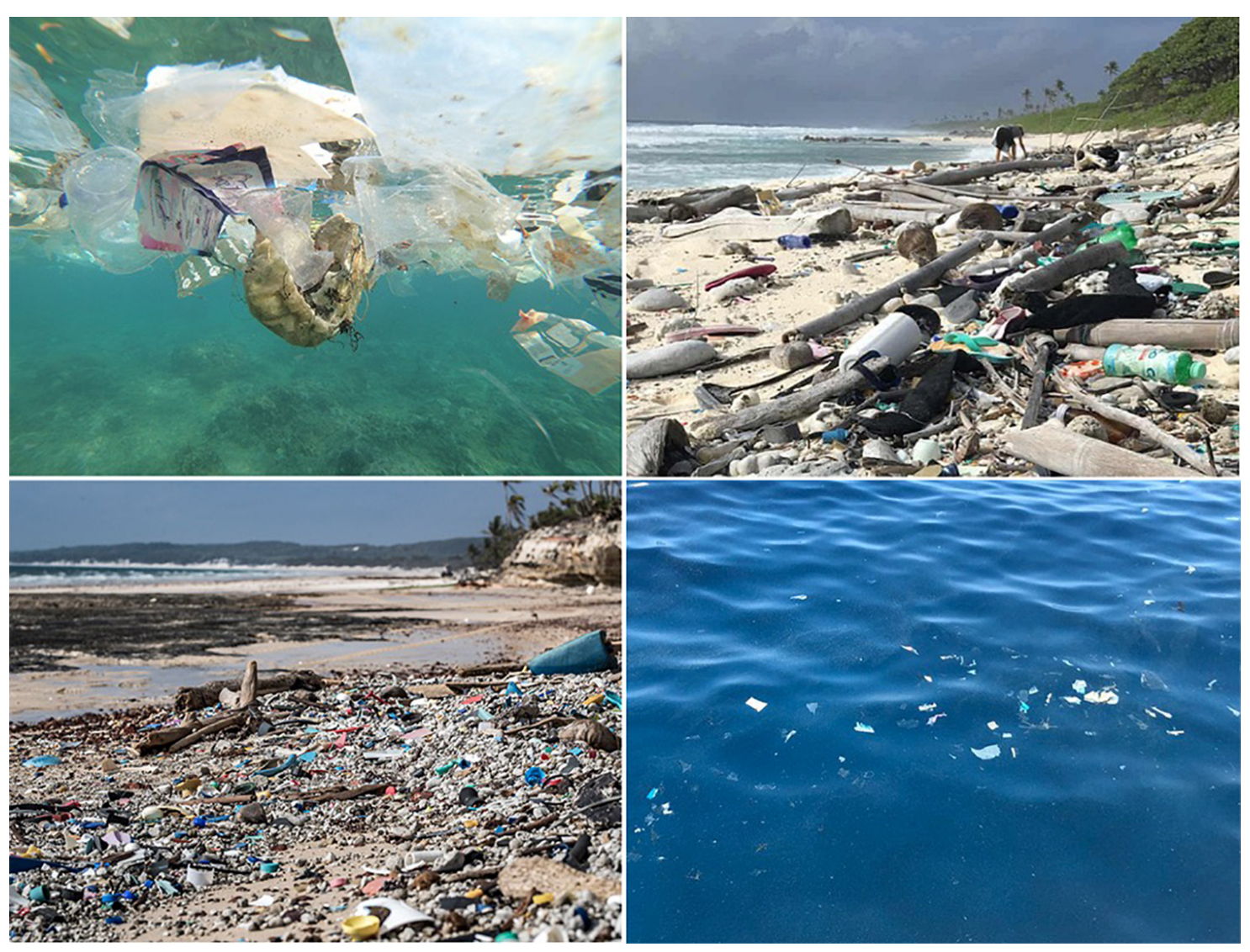

FIGURE 3 | Examples of plastic pollution hotspots in Australia, dominated by Indonesian-based debris. Top right: Christmas Island waters (Image source: Tangaroa Blue); Top left: Cocos Island (Image source: University of Tasmania): Bottom left: Gulf of Carpentaria (Image source: Parley for the Oceans); Bottom right: Ashmore Reef (Image source: Minderoo Foundation).

for national implementation; (3) supporting mechanisms, with a strong multilateral financing component; (4) stringent monitoring, review, compliance, and enforcement processes; and (5) strong involvement of non-governmental stakeholders. To truly solve plastic pollution, we need better worldwide governance, compliance, enforcement, and investments both downstream, by improving waste management systems, and upstream, by decreasing production of fossil fuel-based plastics. The latter can be achieved by incentivizing the replacement of fossil fuel-based plastics with recycled content and/or renewable bio-benign polymers. Setting a "plastic price" that incorporates the external costs of plastic pollution into the price of fossil fuel-based plastics would certainly incentivize their replacement with renewable and/or recycled materials (Raubenheimer and McIlgorm, 2018). Non-binding businessled proposals for implementing a transnational "plastic price" based on a production levy (Forrest et al., 2019) and credit scheme (3R Initiative, 2020) have been made in the past, but so far with very little implementation traction. We encourage policymakers to consider the implementation of a similar, but legally binding, intervention; perhaps under a "Global Extended Producer Responsibility" scheme (Raubenheimer and Urho, 2020) and/or via the introduction of phased targets reducing international trade of fossil-fuel based plastics (Raubenheimer and McIlgorm, 2017).

Mitigating plastic pollution in Australia and further afield also requires a systemic improvement to existing law, policy, and practice at the national level (Table 3). Australian government agencies and regulators need to move beyond the identification of barriers, capacity gaps, needs, and measures and start to scale implementation of state-of-the-art standards in waste segregation, collection, sorting, exports, composting, and recycling practices across its states and territories. While the country's waste collection infrastructure and operations are of relatively high quality, its waste sorting, recycling, and composting operations require considerable improvement. Furthermore, efforts are needed to reduce production and consumption of virgin fossil fuel-based plastics, including incentivizing development and use of substitutes. We believe that key regulatory measures requiring prioritized implementation include:

- Creation of a national bin system that enables citizens to separate waste into standardized higher value material streams (Mühle et al., 2010); 
TABLE 2 | Examples of international initiatives to mitigate plastic pollution.

\begin{tabular}{|c|c|c|}
\hline Name & Year & Description \\
\hline $\begin{array}{l}\text { Convention on the Prevention of Marine } \\
\text { Pollution by Dumping of Wastes and Other } \\
\text { Matter; also known as London }\end{array}$ & 1972/1996 & $\begin{array}{l}\text { Protects the marine environment from pollution. The LC was amended by the London Protocol to } \\
\text { prohibit the deliberate disposal of waste at sea unless it is listed on Annex I, and permits are needed to } \\
\text { dump waste on Annex II. This "reverse list" approach essentially banned the dumping of plastic at sea. }\end{array}$ \\
\hline
\end{tabular}

Convention (LC) ${ }^{1}$

International Convention for the Prevention of Pollution from Ships (MARPOL) ${ }^{2}$

United Nations Convention on the Law of the Sea (UNCLOS, 2020) ${ }^{3}$

1973/1978 Prevents pollution of the marine environment by ships. Annex V prohibits at-sea disposal of plastics by vessels in both exclusive economic zones and waters beyond national jurisdictions.

1982 Establishes rules governing all uses of the oceans and their resources. It does not specifically mention plastics, but broadly calls on states to "protect and preserve the marine environment" (Art 192), including marine pollution (Art 194). In addition, states are required to "adopt laws and regulations to prevent, reduce, and control pollution of the marine environment from land-based sources..." (Art 207).

Basel Convention on the Control of 1989/2019 Aims to prevent environmental and health damage by hazardous waste. It was recently amended to classify certain types of traded plastic waste as hazardous and therefore subject to prior informed consent (PIC) procedure, which is a mechanism for obtaining decisions from importing nations as to whether they wish to receive shipments and for ensuring compliance with these decisions by exporting nations. This amendment will become effective in early 2021.

Code of Conduct for Responsible Fisheries (the Code) ${ }^{5}$

1991

Non-binding instrument to establish principles for responsible fishing and fisheries activities initiated by the Food and Agriculture Organization of the United Nations (FAO). Although plastics are not specifically mentioned, it makes ports and harbors responsible for providing adequate disposal systems for a very problematic type of plastic: fishing nets.

Agenda $21^{6}$

1992

Non-binding plan of action to be taken "in every area in which human impacts on the environment." It acknowledges the degradation of the marine environment by litter (17.18) and encourages the transfer of technology to maximize environmentally sound waste use and recycling (para 21.23).

Global Program of Action for the Protection of the Marine Environment from

Land-based Activities (GPA) ${ }^{7}$

Stockholm Convention on Persistent

Organic Pollutants (POPs) ${ }^{8}$

1995

Non-binding mechanism addressing the connectivity between terrestrial, freshwater, coastal, and marine ecosystems. It advises authorities to reduce the amount of litter produced, improve the management of waste, and up-scale recycling (Art 144).

2001 Protects human health and the environment from POPs. The production, use, and disposal of harmful plastic additives can be regulated by this instrument, but the control is limited to plastic substances listed in the convention.

Honolulu Strategy 9

Manila Declaration ${ }^{10}$

2030 Agenda for Sustainable Development ${ }^{11}$

2015 Non-binding instrument that sets out a number of "soft" goals to reduce marine debris; e.g., capacity building and waste monitoring. It does not define binding plastic pollution reduction targets.

Non-binding commitment to develop policies for reduction and control of wastewater, marine litter, and fertilizer pollution. It contains actions to be taken between 2012 and 2016 at international, regional, and local levels.

Non-binding Plan of Action for people, planet and prosperity. Commits to prevent and significantly reduce marine debris by 2025 (Sustainable Development Goal SDG 14.1). It also has goals related to the treatment of wastewater (SDG 6), waste management (SDG 11), reduction in use of hazardous chemicals (SDG 3), sustainable production and consumption (SDG 12).

New Plastics Economy Global Commitment ${ }^{12}$
Non-binding instrument with 450 + signatories (e.g., companies representing $20 \%$ of all plastic packaging produced globally) committed to (1) eliminate all problematic and unnecessary plastic items; (2) innovate to ensure plastics are reusable, recyclable, or compostable; and (3) circulate plastic items to keep them in the economy and out of the environment.

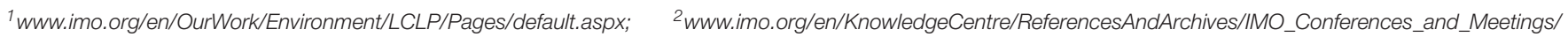

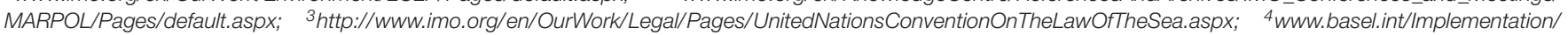

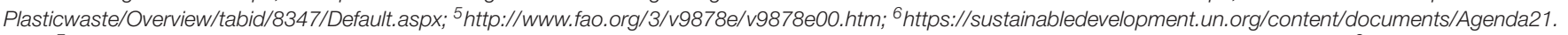

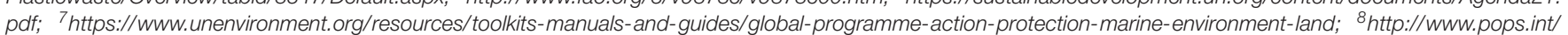

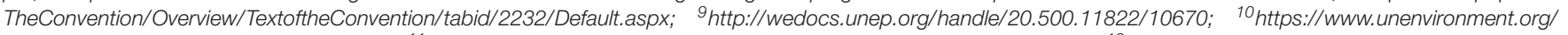

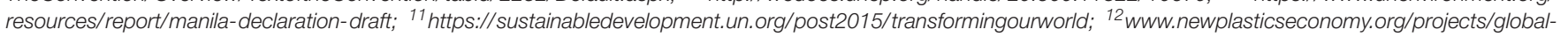
commitment.

- Use of advanced plastic sorting laser technologies in Material Recovery Facilities (MRFs) for production of higher quality polymer bales (Hopewell et al., 2009);

- Banning of unnecessary plastic items, hazardous additives, and polymers (World Economic Forum et al., 2016);

- Support to novel "reuse" business models (Ellen MacArthur Foundation, 2019);

- Investments in innovations to:
- Switch from fossil fuel-based plastics to renewable and bio-benign alternatives (Zheng and Suh, 2019).

○ Redesign problematic items (e.g., multi-layered packaging, plastic films) to make their recycling or composting economically and technically possible;

- Improve technologies able to turn plastic waste into food-grade recycled pellets (Pohjakallio and Vuorinen, 2020). 
TABLE 3 | Examples of Australian national initiatives to mitigate plastic pollution.

\begin{tabular}{|c|c|c|}
\hline Name & Year & Description \\
\hline $\begin{array}{l}\text { Environment Protection (Sea Dumping) } \\
\text { Act } 1981^{1}\end{array}$ & 1981 & $\begin{array}{l}\text { Aims to minimize marine pollution threats by (1) prohibiting ocean disposal of waste considered too } \\
\text { harmful to be released in the marine environment and (2) regulating permitted waste disposal to ensure } \\
\text { environmental impacts are minimized. Plastic waste is not directly addressed in this Act. }\end{array}$ \\
\hline $\begin{array}{l}\text { Protection of the Sea (Prevention of } \\
\text { Pollution from Ships) Act } 1983^{2}\end{array}$ & 1983 & $\begin{array}{l}\text { Prohibits discharge of certain types of garbage into the sea, including plastics such as ropes, fishing } \\
\text { nets, garbage bags, and ashes from burned plastics. }\end{array}$ \\
\hline $\begin{array}{l}\text { Hazardous Waste (Regulation of } \\
\text { Exports and Imports) Act } 1989^{3}\end{array}$ & 1989 & $\begin{array}{l}\text { Regulates the export, import, and transit of hazardous waste to ensure that they are dealt with } \\
\text { appropriately so that human beings and the environment, both within and outside Australia, are } \\
\text { protected from its harmful effects. Plastic waste is not directly mentioned in the Act. }\end{array}$ \\
\hline $\begin{array}{l}\text { National Strategy for Ecologically } \\
\text { Sustainable Development }{ }^{4}\end{array}$ & 1992 & $\begin{array}{l}\text { Facilitates a coordinated and co-operative approach to ecologically sustainable development in } \\
\text { Australia. It does not mention plastics directly. This commitment forms the basis for the } 2009 \text { National } \\
\text { Waste Policy for Australia (see below). }\end{array}$ \\
\hline $\begin{array}{l}\text { Environment Protection and Biodiversity } \\
\text { Conservation Act } 1999 \text { (EPBC Act) }\end{array}$ & 1999 & $\begin{array}{l}\text { Provides a legal framework to protect and manage nationally and internationally important flora, fauna, } \\
\text { ecological communities, and heritage places. It lists "Injury and fatality to vertebrate marine life caused } \\
\text { by ingestion of, or entanglement in, harmful marine debris" as a key threatening process, and considers } \\
\text { that at least } 20 \text { endangered and vulnerable species listed under the EPBC Act may be adversely } \\
\text { affected by marine debris. }\end{array}$ \\
\hline $\begin{array}{l}\text { Australian Packaging Covenant (the } \\
\text { Covenant) }\end{array}$ & 1999 & $\begin{array}{l}\text { The Covenant is an agreement between the packaging industry and Australian governments to reduce } \\
\text { the environmental impacts of packaging. Its } 2019 \text { strategic plan has four targets to be achieved by } \\
2025 \text { : (1) } 100 \% \text { of packaging to be reusable, recyclable or compostable, (2) } 70 \% \text { of packaging recycled } \\
\text { or composted, (3) 30\% average recycled content across all packaging, and (4) phase out problematic } \\
\text { and unnecessary single-use plastic packaging through redesign, innovation, or alternative delivery } \\
\text { methods. }\end{array}$ \\
\hline $\begin{array}{l}\text { Threat Abatement Plan for the Impacts } \\
\text { for Marine Debris on Vertebrate Marine } \\
\text { Life }^{7}\end{array}$ & 2009/2018 & $\begin{array}{l}\text { Postulated under EPBC Act (above), this plan incorporates actions to abate sources of marine debris } \\
\text { under a coordinated national approach. It binds the Commonwealth and its agencies to respond to the } \\
\text { impact of marine debris on vertebrate marine life, and identifies the research, management, and other } \\
\text { actions needed to reduce the impacts of marine debris on the affected species. }\end{array}$ \\
\hline National Waste Policy ${ }^{8}$ & 2009/2018 & $\begin{array}{l}\text { Provides a framework for collaborative action by businesses, governments, communities, and } \\
\text { individuals for waste and resource recovery in Australia. It identifies five overarching principles: (1) avoid } \\
\text { waste, (2) improve resource recovery, (3) increase use of recycled material, (4) better manage material } \\
\text { flows, and (5) improve information to support innovation, guide investment, and consumer decisions. }\end{array}$ \\
\hline $\begin{array}{l}\text { National Environment Protection (Used } \\
\text { Packaging Materials) Measure } 2011^{9}\end{array}$ & 2011 & $\begin{array}{l}\text { Aims to reduce environmental degradation arising from the disposal of used packaging and conserve } \\
\text { virgin materials through the encouragement of waste avoidance and the re-use and recycling of used } \\
\text { packaging materials by supporting and complementing the voluntary strategies in the Covenant (see } \\
\text { above) and by assisting the assessment of the performance of the Covenant. }\end{array}$ \\
\hline Reef 2050 Plan $^{10}$ & 2015 & $\begin{array}{l}\text { Overarching framework for protecting and managing the Great Barrier Reef, which was recognized as a } \\
\text { World Heritage property in 1981. It includes actions to protect the marine environment and wildlife from } \\
\text { harmful materials and debris and allocation of funds toward increasing community engagement in Reef } \\
\text { protection through activities such as coastal clean-ups. }\end{array}$ \\
\hline
\end{tabular}

${ }^{1}$ https://www.legislation.gov.au/Details/C2016C00778; ${ }^{2}$ https://www.legislation.gov.au/Details/C2004C00098; ${ }^{3}$ https://www.legislation.gov.au/Details/C2017C00194; ${ }^{4}$ http://www.environment.gov.au/about-us/esd/publications/national-esd-strategy; ${ }^{5}$ https://www.environment.gov.au/epbc; ${ }^{6}$ https://www.environment.gov.au/ protection/waste-resource-recovery/publications/australian-packaging-covenant-2017; ${ }^{7}$ https://www.environment.gov.au/system/files/resources/e3318495-2389-4ffcb734-164cdd67fe19/files/tap-marine-debris-2018.pdf; ${ }^{8} \mathrm{https://www.environment.gov.au/protection/waste-resource-recovery/national-waste-policy;}{ }^{9} \mathrm{https}: / / \mathrm{www}$.

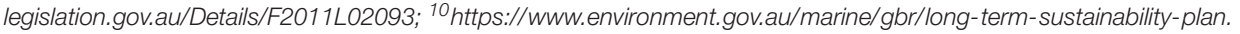

As demonstrated in this study, Australia is both an emitter and receiver of plastic pollution to/from neighboring countries. Therefore, it needs a robust international engagement strategy to complement current National Policies (e.g., Australian Government, 2019). If building responsible recycled plastic trade is deemed to be more beneficial than solely relying on isolated Australian-only operations, agreements involving transboundary deployments of technical and financial resources in waste management and recycling ecosystems should become major priorities. This would ensure regional-scale economic, social, and environmental targets are reached and associated risks minimized (Government of Indonesia, 2017; ASEAN, 2020; DFAT, 2020). Of paramount importance here is for Australia to be accountable for the quality and appropriate management of shipped waste by the receiving entities. This could be effectively implemented via the application of traceability technologies (e.g., Blockchain) enabling tracking of plastic waste movements and transactions under a harmonized material code classification and requiring trade players to adhere to a comprehensive set of requirements in order to participate (e.g., sufficient waste management infrastructure). This type of tracking technology could also assist LMICs with implementing a plastic waste import tax to fund the development of their domestic solid waste management infrastructure. If successfully implemented, responsible international recycled plastic trade could be economically and environmentally beneficial to both Australia and importing nations due to a holistic improvement in regional waste management ecosystems. By improving waste management both domestically and in LMICs importing recyclables, Australia could simultaneously (1) decrease the 
proportions of Australian plastic waste mismanaged and landfilled, (2) contribute to LMICs sustainable development via boosting their waste management and creating jobs, and (3) substantially decrease loads of plastic leakages to oceans. Of upmost importance to the success of international plastic recycling systems is for HICs such as Australia to support LMICs by drastically improving the collection and sortation of their own domestic plastic waste; otherwise, the local recycling operations will continue to rely on overseas feedstock and the leakages to the environment will remain substantial.

Finally, even if Australia stops exporting plastic waste overseas as recently announced by the federal government (Australian Government, 2019; CoAG, 2020), there would still be a need for strong foreign engagement given the substantial OP sources surrounding Australia and the occurrence of overseas OP in Australian waters (MOFA, 2011; ASEAN, 2017, 2019a,b). It is time for Australia to show stronger environmental leadership on the international stage by facilitating and supporting existing and future transnational cooperation (IORA, 2017) and perhaps co-funding waste management infrastructure where it is most needed. In the same way Australia and other HICs use foreign policy aid to help build schools and hospitals in LMICs, we can contribute to implementing better waste management in places where the gap between social development and said infrastructure is the highest (Schnurr and Walker, 2019). Of particular relevance here is our study's demonstration of the strong connectivity between the Australian and Indonesian plastic crises. Indonesia is not only a major player in the Australian plastic waste trade (i.e., $\sim 22 \%$ of Australian plastic waste exports reach Indonesia) but also a major source of OP (e.g., $\sim 70 \%$ of the overseas OP reaching Australia is from Indonesia). Therefore, strong bilateral approaches with Indonesia are particularly important for reducing plastic pollution in Australian waters and surroundings seas (Government of Indonesia, 2017; Marsdon, 2019; DFAT, 2020). Supporting Indonesia will not only benefit Australia's own national interests but may also induce a knock-on effect by encouraging other HICs to show greater global responsibility (Schnurr and Walker, 2019).

\section{FINAL REMARKS}

Plastic emissions into the environment have accelerated at a pace commensurate with plastic production. This, combined

\section{REFERENCES}

3R Initiative (2020). Available online at: www.3rinitiative.org/solutions (accessed May 1, 2020).

ASEAN (2017). ASEAN Framework of Action on Marine Debris. Jakarta: ASEAN.

ASEAN (2019a). Bangkok Declaration on Combating Marine Debris in ASEAN Region. Jakarta: ASEAN.

ASEAN (2019b). Norway funds US\$3 Million Project in Combating Marine Plastic Debris in ASEAN. Jakarta: ASEAN.

ASEAN (2020). ASEAN-Australia relations | ASEAN Australia. Jakarta: ASEAN.

Australian Government (2019). National Waste Policy Action Plan. Available online at: https://www.environment.gov.au/system/files/resources/5b86c9f8-074e- with the serious flow-on effects of plastic pollution on wildlife, economies, and human well-being, necessitates the urgent development and implementation of legislation and legally binding agreements on the production, use, and management of plastics, capable of keeping pace with the scale of this growing problem. Of upmost importance is for governments to move beyond recommendations and longterm non-binding commitments, and to start supporting transformative options, their implementation, and enforcement efforts, with clear and measurable progress targets and indicators. Since many issues found throughout the lifecycle of plastics are transboundary in nature, eradicating them will require a clear and binding global commitment to eliminate plastic contamination of our water, food, air, land, and oceans. An advantage related to plastic pollution when compared to other globally connected problems is that this issue is highly visible, has no deniers, and is receiving increasing public attention globally. Perhaps the wide acceptance of the urgency to act upon the transnational plastic crisis will act as a lever to pioneer an effective global regime that rapidly and costeffectively (1) mitigates a serious transboundary problem and (2) serves as a flagship to catalyze similar undertakings on an even more serious issue that also results from our reliance on fossil fuels: climate change. The pace and scale of our solutions to pollution must start to match the pace and scale of emissions.

\section{AUTHOR CONTRIBUTIONS}

JR, RG, and LL designed the study and analyzed the data. JR and RG prepared figures. JR, RG, and ET wrote the manuscript. All authors reviewed the manuscript.

\section{ACKNOWLEDGMENTS}

The authors thank The University of Western Australia, the Ocean Cleanup Foundation, and the Australian Institute of Marine Science for supporting this study. They also thank Julian Partridge, Marie-Lise Schlappy, and Heidi Tait for input in earlier versions of this manuscript.

4d66-ab11-08bbc69da240/files/national-waste-policy-action-plan-2019.pdf (accessed May 9, 2020).

Barnes, D. K. A. (2002). Invasions by marine life on plastic debris. Nature 416, 808-809. doi: 10.1038/416808a

Borrelle, S. B., Rochman, C. M., Liboiron, M., Bond, A. L., Lusher, A., Bradshaw, H., et al. (2017). Opinion: why we need an international agreement on marine plastic pollution. Proc. Natl. Acad. Sci. U.S.A. 114, 9994-9997. doi: 10.1073/ pnas.1714450114

Brooks, A. L., Wang, S., and Jambeck, J. R. (2018). The Chinese import ban and its impact on global plastic waste trade. Sci. Adv. 4:eaat0131. doi: 10.1126/sciadv. aat0131

Brophy, J. T., Keith, M. M., Watterson, A., Park, R., Gilbertson, M., MatickaTyndale, E., et al. (2012). Breast cancer risk in relation to occupations with 
exposure to carcinogens and endocrine disruptors: a Canadian case-control study. Environ. Health 11:87. doi: 10.1186/1476-069X-11-87

Chen, Q., Reisser, J., Cunsolo, S., Kwadijk, C., Kotterman, M., Proietti, M., et al. (2018). Pollutants in plastics within the north Pacific subtropical gyre. Environ. Sci. Technol. 52, 446-456. doi: 10.1021/acs.est.7b04682

CNN (2019). Plastic Waste Dumped in Malaysia will be returned to UK, US and others. Atlanta: CNN.

CoAG (2020). Phasing Out Exports of Waste Plastic, Paper, Glass and Tyres. Response Strategy to Implement the August 2019 agreement of the Council of Australian Govenment. Canberra: CoAG.

Cohen, S., Martinez, H., and Schroder, A. (2015). Waste Management Practices in New York City, Hong Kong and Beijing. Available online at: http://www. columbia.edu/dsc32 (accessed May 1, 2020).

Commonwealth of Australia (2018a). National Waste Policy: Less Waste More Resources. Canberra: Commonwealth of Australia.

Commonwealth of Australia (2018b). Threat Abatement Plan for the Impacts of Marine Debris on The Vertebrate Wildlife of Australia's Coasts and Oceans. Canberra: Commonwealth of Australia.

Critchell, K., and Lambrechts, J. (2016). Modelling accumulation of marine plastics in the coastal zone; what are the dominant physical processes? Estuar. Coast. Shelf Sci. 171, 111-122. doi: 10.1016/j.ecss.2016.01.036

Cummings, J. A. (2005). Operational multivariate ocean data assimilation. Q. J. R. Meteorol. Soc. 131, 3583-3604. doi: 10.1256/qj.05.105

Cummings, J. A., and Smedstad, O. M. (2013). "Variational data assimilation for the global ocean," in Data Assimilation for Atmospheric, Oceanic and Hydrologic Applications, Vol. II, eds S. K. Park and L. Xu (Berlin: Springer), 303-343. doi: 10.1007/978-3-642-35088-7_13

DeMatteo, R., Keith, M. M., Brophy, J. T., Wordsworth, A., Watterson, A. E., Beck, M., et al. (2013). Chemical exposures of women workers in the plastics industry with particular reference to breast cancer and reproductive hazards. New Solut. 22, 427-448. doi: 10.2190/ns.22.4.d

DFAT (2020). Department of Foreign Affairs and Trade: Joint Declaration of Maritime Cooperation Between the Government of Australia and the Government of the Republic of Indonesia. Barton ACT: DFAT.

Dhimurru Aboriginal Corporation (2018). 2017-2018 Annual report Dhimurru Aboriginal Corporation. Nhulunbuy NT: Dhimurru Aboriginal Corporation.

Ellen MacArthur Foundation (2019). Reuse Rethinking Packaging. Cowes: Ellen MacArthur Foundation.

Eriksen, M., Lebreton, L. C., Carson, H. S., Thiel, M., Moore, C. J., Borerro, J. C., et al. (2014). Plastic pollution in the world's oceans: more than 5 trillion plastic pieces weighing over 250,000 tons afloat at sea. PLoS One 9:e111913. doi: 10.1371/journal.pone.0111913

European Commission (2019). Report from the Commission to the European Parliament, the Council, the European Economic and Social Committee and the Committee of the Regions on the implementation of the Circular Economy Action Plan. Brussels: European Commission.

Forrest, A., Giacovazzi, L., Dunlop, S., Reisser, J., Tickler, D., Jamieson, A., et al. (2019). Eliminating plastic pollution: how a voluntary contribution from industry will drive the circular plastics economy. Front. Mar. Sci. 6:627. doi: 10.3389/fmars.2019.00627

Fox, D. N., Teague, W. J., Barron, C. N., Carnes, M. R., and Lee, C. M. (2002). The Modular Ocean Data Assimilation System (MODAS). J. Atmosph. Oceanic Technol. 19, 13.

GAIA (2019). Discarded: Communities on the Frontlines of the Global Plastic Crisis. Berkeley, CA: Global Alliance for Incinerator Alternatives.

Geyer, R., Jambeck, J. R., and Law, K. L. (2017). Production, use, and fate of all plastics ever made. Sci. Adv. 3:e1700782. doi: 10.1126/sciadv.1700782

Gigault, J., ter Halle, A., Baudrimont, M., Pascal, P.-Y., Gauffre, F., Phi, T.-L., et al. (2018). Current opinion: what is a nanoplastic?. Environ. Pollut. 235, 1030-1034. doi: 10.1016/j.envpol.2018.01.024

Government of Indonesia (2017). Plan of Action for Implementation of the Joint Declaration of Maritime Cooperation Between the Government of the Republic of Indonesia and the Government of Australia. Available online at: http:// treaty.kemlu.go.id/apisearch/pdf?filename=AUS-2018-0238.pdf (accessed May 9, 2020).

Haward, M. (2018). Plastic pollution of the world's seas and oceans as a contemporary challenge in ocean governance. Nat. Commun. 9:667. doi: 10. 1038/s41467-018-03104-3103
Hoornweg, D., and Bhada-Tata, P. (2012). What a Waste: A Global Review of Solid Waste Management. Washington, DC: World Bank.

Hopewell, J., Dvorak, R., and Kosior, E. (2009). Plastics recycling: challenges and opportunities. Philos. Trans. R. Soc. B 364, 2115-2126. doi: 10.1098/rstb.2008. 0311

IORA (2017). Declaration of the Indian Ocean Rim Association on the Blue Economy in the Indian Ocean Region. Ebene: IORA.

Jambeck, J. R., Geyer, R., Wilcox, C., Siegler, T. R., Perryman, M., Andrady, A., et al. (2015). Plastic waste inputs from land into the ocean. Science 347, 768-771. doi: 10.1126/science. 1260352

Lamb, J. B., Willis, B. L., Fiorenza, E. A., Couch, C. S., Howard, R., Rader, D. N., et al. (2018). Plastic waste associated with disease on coral reefs. Science 359, 460-462. doi: 10.1126/science.aar3320

Lavers, J. L., and Bond, A. L. (2017). Exceptional and rapid accumulation of anthropogenic debris on one of the world's most remote and pristine islands. PNAS 114, 6052-6055. doi: 10.1073/pnas.1619818114

Lavers, J. L., Dicks, L., Dicks, M. R., and Finger, A. (2019). Significant plastic accumulation on the Cocos (Keeling) Islands, Australia. Sci. Rep. 9, 1-9. doi: 10.1038/s41598-019-43375-43374

Lavers, J. L., Hodgson, J. C., and Clarke, R. H. (2013). Prevalence and composition of marine debris in Brown Booby (Sula leucogaster) nests at Ashmore Reef. Mar. Pollut. Bull. 77, 320-324. doi: 10.1016/j.marpolbul.2013.09.026

Lavers, J. L., Sharp, P. B., Stuckenbrock, S., and Bond, A. L. (2020). Entrapment in plastic debris endangers hermit crabs. J. Hazardous Mater. 387:121703. doi: 10.1016/j.jhazmat.2019.121703

Lebreton, L., Slat, B., Ferrari, F., Sainte-Rose, B., Aitken, J., Marthouse, R., et al. (2018). Evidence that the Great Pacific Garbage Patch is rapidly accumulating plastic. Sci. Rep. 8, 1-15. doi: 10.1038/s41598-018-22939-w

Lebreton, L. C.-M., Greer, S. D., and Borrero, J. C. (2012). Numerical modelling of floating debris in the world's oceans. Mar. Pollut. Bull. 64, 653-661. doi: 10.1016/j.marpolbul.2011.10.027

Lebreton, L. C. M., van der Zwet, J., Damsteeg, J.-W., Slat, B., Andrady, A., and Reisser, J. (2017). River plastic emissions to the world's oceans. Nat. Commun. 8:15611. doi: 10.1038/ncomms15611

Lehner, R., Weder, C., Petri-Fink, A., and Rothen-Rutishauser, B. (2019). Emergence of nanoplastic in the environment and possible impact on human health. Environ. Sci. Technol. 53, 1748-1765. doi: 10.1021/acs.est.8b05512

Liu, Z., Adams, M., and Walker, T. R. (2018). Are exports of recyclables from developed to developing countries waste pollution transfer or part of the global circular economy? Resour. Conserv. Recycling 136, 22-23. doi: 10.1016/ j.resconrec.2018.04.005

Locock, K. (2017). The Recycled Plastics Market: Global Analysis and Trends. Australia: CSIRO.

Manikkam, M., Tracey, R., Guerrero-Bosagna, C., and Skinner, M. K. (2013). Plastics Derived Endocrine Disruptors (BPA, DEHP and DBP) induce epigenetic transgenerational inheritance of obesity, reproductive disease and sperm Epimutations. PLoS One 8:e55387. doi: 10.1371/journal.pone.005 5387

Marsdon, K. (2019). Marine Plastics in Northern Australian Waters: Targeted Aid Will Help Indonesia to help Us. Future Directions International. Available online at: http://www.futuredirections.org.au/publication/marine-plasticsin-northern-australian-waters-targeted-aid-will-help-indonesia-to-help-us/ (accessed April 30, 2020).

Martin, C., Almahasheer, H., and Duarte, C. M. (2019). Mangrove forests as traps for marine litter. Environ. Pollut. 247, 499-508. doi: 10.1016/j.envpol.2019. 01.067

MOFA (2011). MOFA: ASEAN+3 Summit Meetings. Riyadh: MOFA.

Mühle, S., Balsam, I., and Cheeseman, C. R. (2010). Comparison of carbon emissions associated with municipal solid waste management in Germany and the UK. Resour. Conserv. Recycling 54, 793-801. doi: 10.1016/j.resconrec.2009. 12.009

Olivelli, A., Hardesty, D., and Wilcox, C. (2020). Coastal margins and backshores represent a major sink for marine debris: insights from a continentalscale analysis. Environ. Res. Lett. 15:07403. doi: 10.1088/1748-9326/ab 7836

Peeken, I., Primpke, S., Beyer, B., Gütermann, J., Katlein, C., Krumpen, T., et al. (2018). Arctic sea ice is an important temporal sink and means of transport for microplastic. Nat. Commun. 9:1505. 
Pohjakallio, M., and Vuorinen, T. (2020). "Chemical routes for recyclingdissolving, catalytic, and thermochemical technologies," in Plastic Waste and Recycling, Ed. T. M. Letcher (Amsterdam: Elsevier), 359-384. doi: 10.1016/ b978-0-12-817880-5.00013-x

Porter, A., Lyons, B. P., Galloway, T. S., and Lewis, C. (2018). Role of marine snows in microplastic fate and bioavailability. Environ. Sci. Technol. 52, 7111-7119. doi: $10.1021 /$ acs.est.8b01000

Raubenheimer, K., and McIlgorm, A. (2017). Is the Montreal Protocol a model that can help solve the global marine plastic debris problem? Mar. Policy 81, 322-329. doi: 10.1016/j.marpol.2017.04.014

Raubenheimer, K., and McIlgorm, A. (2018). Can a global fund help solve the global marine plastic debris problem?. J. Ocean Coast. Econ. 5:6. doi: 10.15351/23738456.1078

Raubenheimer, K., and Urho, N. (2020). Rethinking global governance of plastics The role of industry. Mar. Policy 113:103802. doi: 10.1016/j.marpol.2019. 103802

Reisser, J., Shaw, J., Hallegraeff, G., Proietti, M., Barnes, D. K. A., Thums, M., et al. (2014). Millimeter-sized marine plastics: a new pelagic habitat for microorganisms and invertebrates. PLoS One 9:e100289. doi: 10.1371/journal. pone. 0100289

Reisser, J., Shaw, J., Wilcox, C., Hardesty, B. D., Proietti, M., Thums, M., et al. (2013). Marine plastic pollution in waters around Australia: characteristics, concentrations, and pathways. PLoS One 8:e80466. doi: 10.1371/journal.pone. 0080466

Rochman, C. M., Tahir, A., Williams, S. L., Baxa, D. V., Lam, R., Miller, J. T., et al. (2015). Anthropogenic debris in seafood: plastic debris and fibers from textiles in fish and bivalves sold for human consumption. Sci. Rep. 5:14340.

Ryan, P. G. (2013). A simple technique for counting marine debris at sea reveals steep litter gradients between the Straits of Malacca and the Bay of Bengal. Mar. Pollut. Bull. 69, 128-136. doi: 10.1016/j.marpolbul.2013. 01.016

Sarpong, S. (2020). Counting the Cost: Malaysia’s Push-Back Begins over Overseas Waste Dumping. Sociology 57, 77-84. doi: 10.1007/s12115-019-00443-449

Schlining, K., von Thun, S., Kuhnz, L., Schlining, B., Lundsten, L., Jacobsen Stout, N., et al. (2013). Debris in the deep: using a 22 -year video annotation database to survey marine litter in Monterey Canyon, central California, USA. Deep Sea Res. Part I Oceanogr. Res. Papers 79, 96-105. doi: 10.1016/j.dsr.2013. 05.006

Schnurr, R. E., and Walker, T. R. (2019). Should Canada’s foreign aid policy help address the environmental impact of single-use plastics? Proc. Nova Scotian Inst. Sci. 50:35. doi: 10.15273/pnsis.v50i1.8869

Schweitzer, J., Gionfra, S., Pantzar, M., Mottershead, D., Watkins, E., Petsinaris, F., et al. (2018). Unwrapped: How Throwaway Plastic is Failing to Solve Europe's food Waste Problem (and what we need to do instead). Brussels: Institute for European Environmental Policy.

Setälä, O., Fleming-Lehtinen, V., and Lehtiniemi, M. (2014). Ingestion and transfer of microplastics in the planktonic food web. Environ. Pollut. 185, 77-83. doi: 10.1016/j.envpol.2013.10.013

Simon, N., and Schulte, M. L. (2017). Stopping global plastic pollution: the case for an international convention. Ecol. Publ. Ser. 43:56.

Sprintall, J., Gordon, A. L., Wijffels, S. E., Feng, M., Hu, S., Koch-Larrouy, A., et al. (2019). Detecting Change in the Indonesian Seas. Front. Mar. Sci. 6:257. doi: $10.3389 /$ fmars.2019.00257

Tessnow-von Wysocki, I., and Le Billon, P. (2019). Plastics at sea: treaty design for a global solution to marine plastic pollution. Environ. Sci. Policy 100, 94-104. doi: 10.1016/j.envsci.2019.06.005
UN Trade Statistics (2018). United Nations Commodity Trade Statistics Database. Available online at: https://comtrade.un.org/db/default.aspx (accessed July 26, 2019).

UNCLOS (2020). Article 207. Pollution From Land-Based Sources. Montego Bay: UNCLOS.

UNEP (2014). Valuing Plastics: The Business Case for Measuring, Managing and Disclosing Plastic Use in the Consumer Goods Industry. Division of Environmental Policy Implementation. Nairobi: United Nations Environment Programme.

Vegter, A., Barletta, M., Beck, C., Borrero, J., Burton, H., Campbell, M., et al. (2014). Global research priorities to mitigate plastic pollution impacts on marine wildlife. Endang. Species. Res. 25, 225-247. doi: 10.3354/esr00623

Vince, J., and Stoett, P. (2018). From problem to crisis to interdisciplinary solutions: plastic marine debris. Mar.ne Policy 96, 200-203. doi: 10.1016/j. marpol.2018.05.006

Walden, M., and Renaldi, E. (2019). Indonesian Environmentalists Accuse Australia of "smuggling" Plastic Waste Following China ban. ABC News. Available online at: https://www.abc.net.au/news/2019-04-30/australia-accused-of-smugglingplastic-waste-to-indonesia/11054592? nw=0 (accessed May 4, 2020).

Walker, T. R. (2018). China's ban could curb plastic waste. Nature 553, 404-404.

Wang, W., Themelis, N. J., Sun, K., Bourtsalas, A. C., Huang, Q., Zhang, Y., et al. (2019). Current influence of China's ban on plastic waste imports. Waste Dispos. Sustain. Energy 1, 67-78. doi: 10.1007/s42768-019-00005-z

Weikard, H.-P. (2019). Policy note: "Towards an international treaty to fight plastic pollution in water systems: some tasks for economists.". Water Econs. Policy 05:1871004. doi: 10.1142/S2382624X18710042

Wilcox, C., Hardesty, B. D., Sharples, R., Griffin, D. A., Lawson, T. J., and Gunn, R. (2013). Ghostnet impacts on globally threatened turtles, a spatial risk analysis for northern Australia. Conserv. Lett. 6, 247-254. doi: 10.1111/conl. 12001

World Economic Forum, Ellen MacArthur Foundation, McKinsey \& Company (2016). The New Plastics Economy - Rethinking the Future Of Plastics. Available online at: http://www.ellenmacarthurfoundation.org/publications (accessed May 9, 2020).

Yeo, B. G., Takada, H., Taylor, H., Ito, M., Hosoda, J., Allinson, M., et al. (2015). POPs monitoring in Australia and New Zealand using plastic resin pellets, and International Pellet Watch as a tool for education and raising public awareness on plastic debris and POPs. Mar. Pollut. Bull. 101, 137-145. doi: 10.1016/j. marpolbul.2015.11.006

Zheng, J., and Suh, S. (2019). Strategies to reduce the global carbon footprint of plastics. Nat. Clim. Change 9, 374-378. doi: 10.1038/s41558-019-0459-z

Conflict of Interest: LL is employed by the company The Modelling House Ltd.

The remaining authors declare that the research was conducted in the absence of any commercial or financial relationships that could be construed as a potential conflict of interest.

Copyright (๑) 2020 Galaiduk, Lebreton, Techera and Reisser. This is an open-access article distributed under the terms of the Creative Commons Attribution License (CC BY). The use, distribution or reproduction in other forums is permitted, provided the original author(s) and the copyright owner(s) are credited and that the original publication in this journal is cited, in accordance with accepted academic practice. No use, distribution or reproduction is permitted which does not comply with these terms. 